\title{
Reproductive Biology of Round Herring Etrumeus teres (Dekay, 1842 ) from the Egyptian Mediterranean Water at Alexandria
}

\author{
Alaa G. M. Osman,, ${ }^{1,2}$ El Sayed H. Akel, ${ }^{3}$ Mahmoud M. S. Farrag, ${ }^{3}$ and Mohsen A. Moustafa \\ ${ }^{1}$ Department of Zoology, Faculty of Science, Al-Azhar University, Assiut Branch, Assiut 71524, Egypt \\ ${ }^{2}$ Leibniz-Institute of Freshwater Ecology and Inland Fisheries, 12587 Berlin, Germany \\ ${ }^{3}$ Fishery Biology Lab, National Institute of Oceanography and Fisheries, Kait-Bey, Alexandria, Egypt
}

Correspondence should be addressed to Alaa G. M. Osman, osman@igb-berlin.de

Received 24 January 2011; Accepted 1 March 2011

Academic Editors: A. Pagano and A. Robins

Copyright (c) 2011 Alaa G. M. Osman et al. This is an open access article distributed under the Creative Commons Attribution License, which permits unrestricted use, distribution, and reproduction in any medium, provided the original work is properly cited.

Maturity stages of round herring Etrumeus teres were divided anatomically into six stages. Monthly distribution of such maturity stages showed that $E$. teres had prolonged spawning season extended from December to May for females and to July for males. The observed sex ratio was 1:2 (male: female). Gonadosomatic index (GSI) values were high during breeding season for both sexes. Hepatosomatic index (HIS) values for females increased from December to April and from December to July for males. Both sexes of E. teres showed the same correlation between GSI and HSI during their breeding season. The absolute and relative fecundity increased with increasing of length and weight. Histologically, the ovarian cycle of $E$. teres was classified into six stages and the testicular cycle into five stages. Female of E. teres was a multiple spawner and had prolonged spawning season with a group-synchronous ovarian which contained oocytes at all stages of development. Also, different sizes of spermatocytes at different developmental stages of maturation were observed during the same season. This may reflect the suitability of the specific reproductive behavior of male and its adaptation to the prolonged spawning season with females.

\section{Introduction}

Round herring Etrumeus teres (Dekay, 1842) is a subtropical clupeid fish usually aggregating in large schools [1]. It is a zooplanktivorous species, distributed in the eastern Pacific, western Pacific, western Indian Ocean, and Red Sea, with immigrants into the eastern Mediterranean $[2,3]$. Round herring $E$. teres showed rapid distribution at different Mediterranean countries. It was recorded in Mediterranean water for first time by [2]. Successively it has been found in Egypt [4], in Iskenderun Bay in Turkish water [5], in Cyprus water [6], in Lampedusa Island in the Strait of Sicily [7], and in Crete Island in Greece [8]. Round herring, Etrumeus teres mainly caught by purse seine using light [9]. This species takes a unique place in the total landing catch of purseseine at the Egyptian Red Sea; it formed about $25 \%$ of the total purse-seine catch in the Egyptian Red Sea water. In the Egyptian Mediterranean water this species accounted about $16 \%$ of the total catch of purse-seine in the east of Alexandria [10].
Reproduction in fishes is the most important topic in fishery biology [9]. It gives knowledge about fish species and their ability to ensure the continuation. Application of sex ratio is useful to study the total population of fish spawning [11]. Gonadosomatic index (GSI) is an indicator for the sexual cycle of fish species, by which we can determine the time of spawning $[12,13]$. The hepatosomatic index (HSI) can give a picture about ability of fishes to store fatty substances. HSI may be changed according to the variations in the feeding habits and reproductive behavior [14]. Measurements of egg diameter during spawning season give clear information about the mode of spawning, whether prolonged or short [15]. Also, knowledge of fecundity and spawning season of fish helps to manage and maintain such fishery, and they are used to plan fishing tactics [15]. Histological studies can give a good knowledge about structure of gonads and confirm spawning time and mode of spawning of fish species.

The present paper is a part of a detailed investigation on the biology of E. teres. Detailed reproductive studies were 
preceded in the present work to get sufficient information about reproductive characters of Etrumeus teres in the Egyptian Mediterranean water.

\section{Materials and Methods}

2.1. Sampling. A total of 656 specimens of round herring Etrumeus teres were collected monthly from Alexandria landing centers during the period from January to December 2008 (May was closed month). The total length (TL) of each fish was measured to the nearest centimeter $(\mathrm{cm})$. Total and gutted weights of fish were weighed to the nearest gram. The gutted weight was used to avoid any bias resulted from weights of gonads and stomachs. Weights of gonads and liver were recorded to the nearest milligram $(\mathrm{mg})$. The sex and maturity stages of each fish were detected. Gonads were preserved in 10\% formalin for fecundity examination and subsequent histological analysis.

2.2. Maturity Stages. Maturity stages of E. teres were classified according to Nikolsky [16] with some modifications into six maturity stages [immature stage (I), resting stage (II), maturation stage (III), nearly ripe stage (IV), fully ripe stage $(\mathrm{V})$, spent stage $(\mathrm{VI})]$. Maturity stages I and II were together considered as immature. Stage III was considered as mature. Stages IV and V were considered as mature/ripe (running).

2.3. Length and Age at First Sexual Maturity. The length and age at first sexual maturity were obtained as the length or age at which 50 percent of all individuals are sexually mature [17].

2.4. Sex Ratio. It was determined as the percentage of males to females $(\mathrm{M}: \mathrm{F})$. Chi-square test at 0.05 significance level was computed [18].

2.5. Gonadosomatic Index (GSI). Gonadosomatic index (GSI) was performed by using the following formula [19]:

$$
\mathrm{GSI}=\frac{\mathrm{GW} * 100}{\mathrm{~W}},
$$

where GW is the gonad weight $(\mathrm{g})$ and $\mathrm{W}$ is gutted weight (g).

2.6. Hepatosomatic Index (HSI). Hepatosomatic index (HSI) for $E$. teres was estimated as the percentage of liver weight to the gutted body weight by using the following formula [20]:

$$
\mathrm{HSI}=\frac{\text { liver weight }(\mathrm{g}) * 100}{\text { gutted weight }(\mathrm{g})} .
$$

2.7. Fecundity. A total of 70 ovaries were used to investigate fecundity of $E$. teres. Fecundity was processed on right lobe. Three weighted subsamples of eggs were taken. Eggs were weighted to the nearest $0.001 \mathrm{gm}$. Absolute average fecundity of $E$. teres was calculated as the number of eggs per ovary of mature fish during the spawning season [21], according to the following equation $[12,15]$ :

$$
\mathbf{F}=\frac{\mathbf{W}}{\mathbf{w} * \mathbf{X}} .
$$

$\mathbf{W}$ is the weight of gonad. $\mathbf{W}$ is the mean weight of subsamples. $\mathbf{X}$ is the counted number of mature eggs in the sub-sample

Relative fecundity is the number of eggs per unit length or weight of fish. Egg diameter was measured to the nearest $\mathrm{mm}$ by ocular micrometer.

2.8. Histological Studies. Gonads of 100 specimens (males and females) of $E$. teres were collected during the period from January to December 2008 for histological examination. Gonads were fixed in Bouin's solution, dehydrated, embedded in paraffin wax, and sectioned at $4-7 \mu \mathrm{m}$ then stained with haematoxylin and eosin and examined microscopically.

\section{Results}

3.1. Monthly Distribution of Maturity Stages. Monthly variations in the maturity stages of E. teres are shown in Table 1. From such table, it is clear that the period of spawning started in December where the ripe gonads amounted $3.57 \%$ and $9.52 \%$ for males and females, respectively. This species had prolonged spawning season, which started in December for both sexes and ended in early July with high peak in April for males. For females, spawning season may extend to May. Spent fish appeared in June, July, and August for both sexes. Females restarted their reproductive cycle in July while males started their reproductive cycle in August.

3.2. Length and Age at First Sexual Maturity. Figure 1(a) shows that males and females of $E$. teres attained their first sexual maturity at lengths of $13.8 \mathrm{~cm}$ and $13.5 \mathrm{~cm}$, respectively, when they were 2 years old.

\subsection{Sex Ratio}

3.3.1. Variations of Sex Ratio with Length. Females of E. teres were more abundant in all length groups (except for length group $24 \mathrm{~cm} \mathrm{TL}$ ) (Figure 1(b)). The highest values of sex ratio were observed for small sized groups $(\mathrm{M} / \mathrm{F}=1: 4 ; 1: 8$ and $1: 2.8$ for 11,12 and $13 \mathrm{~cm} \mathrm{TL}$, resp.). Sex ratio decreased at the larger sized groups $(\mathrm{M} / \mathrm{F}=1: 0.5$ and $1: 1.3$ for $24 \mathrm{~cm}$ and $25 \mathrm{~cm} \mathrm{TL}$, resp.). The parity was observed only at size group $23 \mathrm{~cm}$.

3.3.2. Monthly Variations of Sex Ratio. Monthly variations of sex ratio for E. teres are shown in Figure 1(c). From such figure, we noticed that females were more abundant throughout the whole period of investigation except for April and December with a peak in March $(\mathrm{M} / \mathrm{F}=1: 17)$. Generally, for most lengths and for the whole period of investigation, females accounted $66.6 \%$ of the total fish with sex ratio $1: 2$. The chi-square value was $72.4(P<.05)$. 
TABLE 1: Monthly distribution of maturity stages of E. teres collected from the Egyptian Mediterranean water of Alexandria during the period from January to December 2008.

\begin{tabular}{|c|c|c|c|c|c|c|c|c|c|c|c|c|}
\hline \multirow{3}{*}{ Month } & \multicolumn{6}{|l|}{ Male maturity stages } & \multicolumn{6}{|c|}{ Female maturity stages } \\
\hline & \multirow{2}{*}{ No. } & II & III & IV & $\mathrm{V}$ & VI & \multirow{2}{*}{ No. } & II & III & IV & $\mathrm{V}$ & VI \\
\hline & & $\%$ & $\%$ & $\%$ & $\%$ & $\%$ & & $\%$ & $\%$ & $\%$ & $\%$ & $\%$ \\
\hline January & 26 & 23.1 & 33.8 & 36.6 & 6.5 & 0 & 54 & 14.81 & 37 & 44.4 & 3.7 & 0 \\
\hline February & 21 & 0 & 28.6 & 47.6 & 23.8 & 0 & 53 & 0 & 26.4 & 64.2 & 9.43 & 0 \\
\hline March & 2 & 0 & 0 & 50 & 50 & 0 & 34 & 0 & 2.94 & 61.8 & 35.3 & 0 \\
\hline April & 70 & 0 & 0 & 10 & 90 & 0 & 31 & 0 & 0 & 25.8 & 74.2 & 0 \\
\hline May & & & & & & & & & & & & \\
\hline June & 18 & 0 & 0 & 22.2 & 27.8 & 50 & 35 & 0 & 5.71 & 0 & 0 & 94.3 \\
\hline July & 10 & 0 & 30 & 20 & 10 & 40 & 63 & 3.175 & 3.17 & 0 & 0 & 93.7 \\
\hline August & 5 & 60 & 0 & 0 & 0 & 40 & 58 & 25.86 & 0 & 0 & 0 & 74.1 \\
\hline September & 4 & 100 & 0 & 0 & 0 & 0 & 21 & 100 & 0 & 0 & 0 & 0 \\
\hline October & 8 & 100 & 0 & 0 & 0 & 0 & 21 & 85.71 & 14.3 & 0 & 0 & 0 \\
\hline November & 27 & 77.8 & 22.2 & 0 & 0 & 0 & 46 & 69.57 & 21.7 & 8.7 & 0 & 0 \\
\hline December & 28 & 23.8 & 28.6 & 44.3 & 3.57 & 0 & 21 & 23.7 & 38.1 & 28.8 & 9.52 & 0 \\
\hline
\end{tabular}

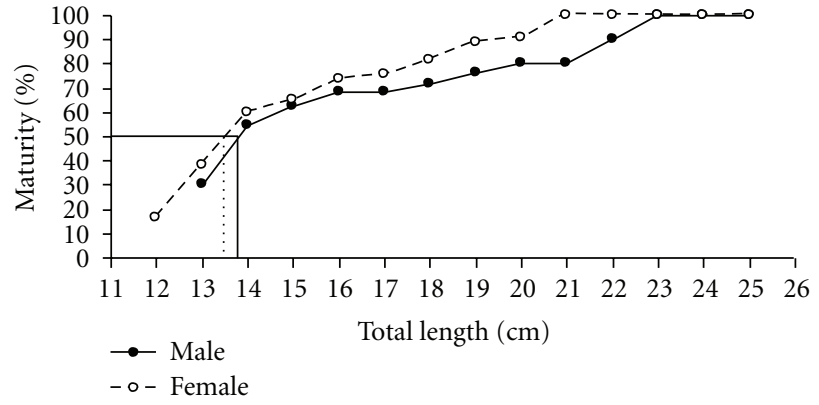

(a)

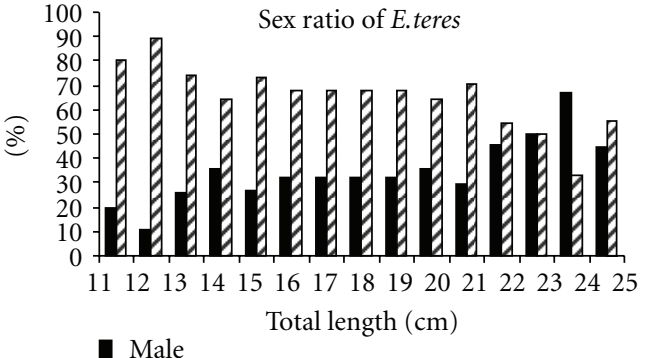

च Female

(b)

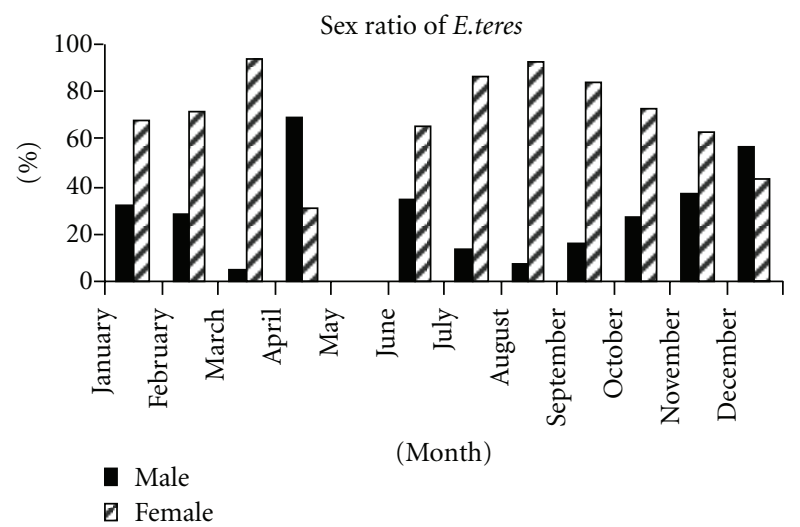

(c)

Figure 1: Length at first sexual maturity (a), variations of sex ratio with length (b), monthly variation of sex ratio (c) for male and female of E. teres collected from the Egyptian Mediterranean water, off Alexandria during the period from January to December 2008.

This value showed highly significant difference between both sexes.

3.4. Gonadosomatic Index. In the present work the gonadosomatic index (GSI) was monthly investigated for both sexes (Figure 2(a)). Males acquired higher GSI than females except in January, September, and December. In both sexes, GSI increased in December $(3.6 \pm 1.5$ and $3.2 \pm 0.9)$ and reached its peak value in April (4.1 \pm 0.8 and 7.4 \pm 1.2$)$ for females and males, respectively. After April the GSI decreased reaching its minimum value in August for females $(0.3 \pm 0.2)$ and in September for males $(0.3 \pm 0.15)$. This proved that the spawning season extended from December for both sexes to May and early July for females and males, respectively. 
GSI of E.teres

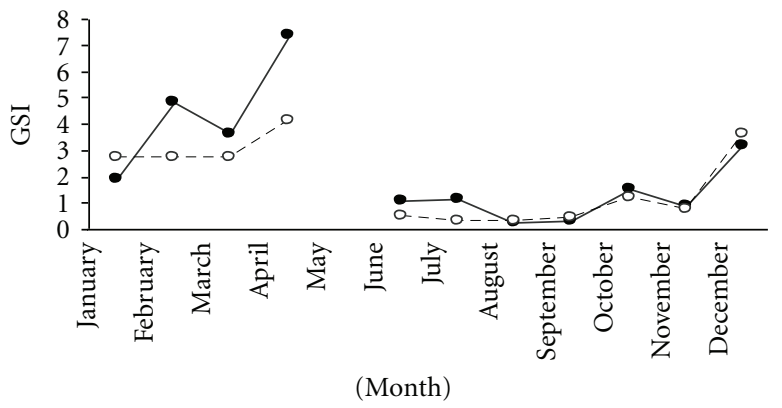

(a)

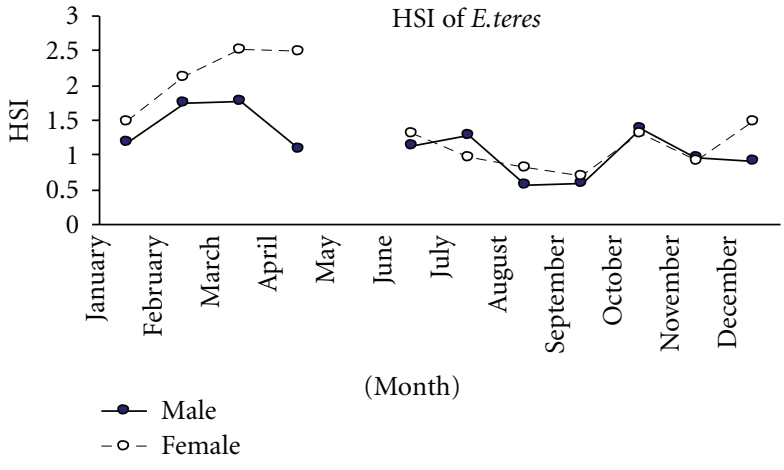

(b)

FIGURE 2: Monthly variations of the gonadosomatic index (GSI) and hepatosomatic index (HSI) for male and female of E. teres collected from the Egyptian Mediterranean water, off Alexandria during the period from January to December 2008.

3.5. Hepatosomatic Index. The monthly variations of the hepatosomatic index (HSI) for both sexes of E. teres are presented in Figure 2(b). From such figure it is obvious that the highest values of HSI were recorded during March and April ( $2.5 \pm 0.4$ and $2.5 \pm 0.5$, resp. $)$ for females. Males acquired the highest values of HSI during February and March ( $1.7 \pm 0.6$ and $1.8 \pm 0.57$, resp.). The lowest values of HSI were recorded during September $(0.7 \pm 0.3$ and $0.6 \pm$ 0.16 for female and male, resp.). Generally, values of HSI for females of $E$. teres were higher than those for males during study period. Both sexes showed higher HSI values during spawning season (Figure 2(b)).

3.6. Egg Diameter. The eggs were divided into two groups according to the maturity stages. The first group included the immature (transparent) eggs with diameter ranging from $0.1 \mathrm{~mm}$ to $0.5 \mathrm{~mm}$. The second group included the yolky (mature and ripe) eggs with diameter ranging from $0.6 \mathrm{~mm}$ to $2.1 \mathrm{~mm}$. Figure 3 shows the variations in egg diameters during the spawning months. In December, the percentage of ova diameter ranged from $0.7 \mathrm{~mm}$ to $1.1 \mathrm{~mm}$ and from $1.5 \mathrm{~mm}$ to $1.9 \mathrm{~mm}$. During such month GSI value was 3.6 and the average fish length was $18 \mathrm{~cm}$. At January, February, and March, the average of fish lengths was $17 \mathrm{~cm}$ and GSI value was 2.7. The percentage of ova diameter showed a remarkable increase. At April, GSI value was the highest (4.1) with average fish length $19 \mathrm{~cm}$. At the same time the percentage of yolky eggs increased. Such progressive increase in the percentage of yolky eggs from December towards April indicated that $E$. teres has prolonged spawning season. The presence of different size groups of immature, mature, and ripe eggs in the ovaries during spawning period of $E$. teres revealed that this fish is multi spawner.

\subsection{Fecundity}

3.7.1. Relationship between Fecundity and Fish Length. From Figures 4(a), 4(b), fecundity increased as the fish grows in length, and the relationship was characterized by a power function equation curve power. The absolute fecundity ranged from 3953 to 12698 for fish length ranging from 14 to $22 \mathrm{~cm}$. The regression equation between the absolute fecundity and fish length was as follows:

$$
\log \mathrm{Fa}=\log 4.341+2.582 \log L, \quad r=0.9600,
$$

where $\mathrm{Fa}$ is the absolute fecundity, $L$ is the total fish length, and $r$ is the correlation coefficient.

Concerning the value of correlation coefficient, the relationship between absolute fecundity and fish length revealed a strong agreement. The relative fecundity increased as the fish grow in length. The relative fecundity ranged from 278 to 645 for fish length ranging from 14 to $22 \mathrm{~cm}$. The relationship between relative fecundity and fish length was as follows:

$$
\log \mathrm{Fr}=\log 2.02+1.86 \log L, \quad r=0.9750,
$$

where $\mathrm{Fr}$ is the relative fecundity, $L$ is the total fish length in $\mathrm{cm}$, and $r$ is the correlation coefficient.

3.7.2. Relationship between Fecundity and Weight. The relationship between gutted weight and fecundity indicated that this relation is curve power (Figures 4(b), 4(c)). From such figure, it was evident that fecundity increased as the fish grew in weight. The absolute fecundity ranged from 4319 to 17247 for fish weight ranging from 25 to $82 \mathrm{~g}$. The regression equation between the absolute fecundity and fish weight was as follows:

$$
\log \mathrm{Fa}=\log 101.34+1.2 \log \mathrm{W}, \quad r=0.980,
$$

where $\mathrm{Fa}$ is the absolute fecundity, $\mathrm{W}$ is the gutted weight in g. and $r$ is the correlation coefficient.

According to the value of correlation coefficient, the relationship between absolute fecundity and fish weight revealed a significant agreement. The relative fecundity increased as the fish grew in weight. The relative fecundity ranged from 179 to 213 for the same weights. The relationship between relative fecundity and fish weight was as follows:

$$
\log \mathrm{Fr}=\log 113.76+0.1 \log \mathrm{W}, \quad r=0.921,
$$

where Fr is the relative fecundity, $\mathrm{W}$ is the gutted weight in g., and $r$ is the correlation coefficient. 


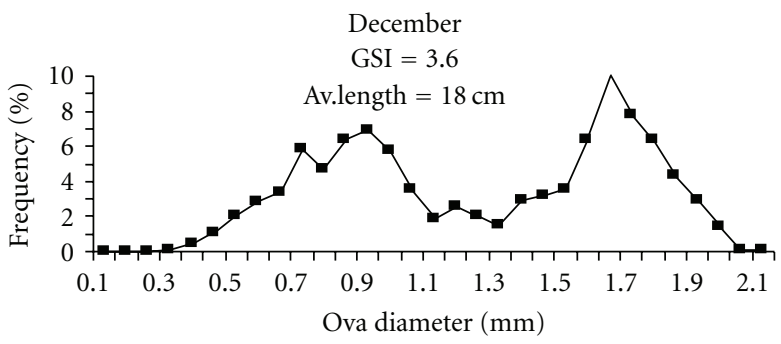

(a)

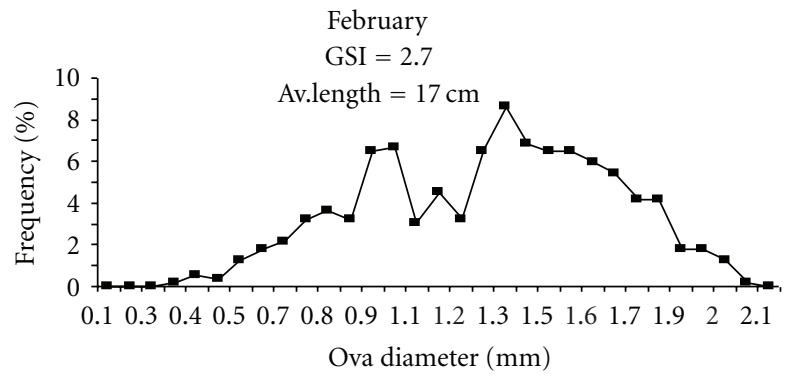

(c)

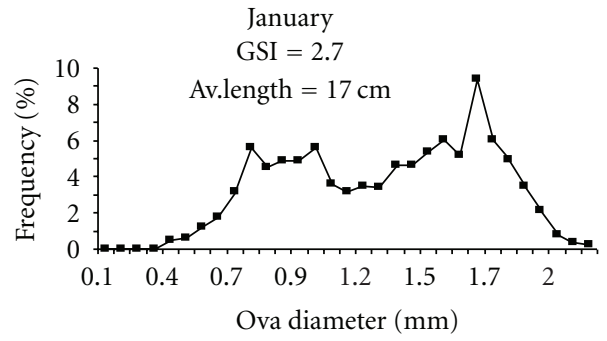

(b)

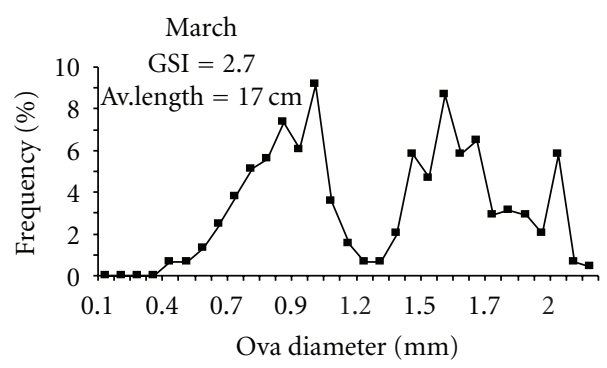

(d)

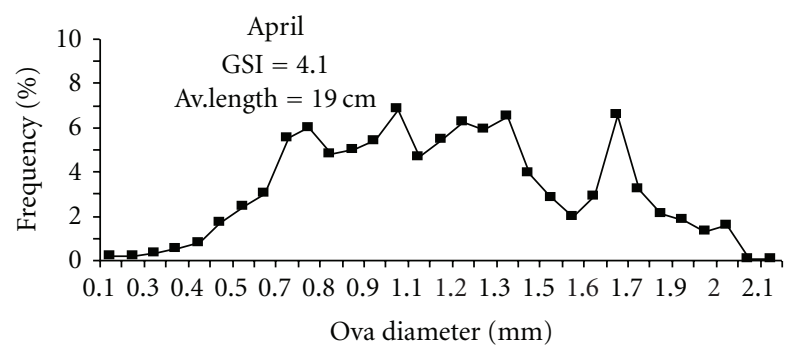

(e)

FIGURE 3: Frequency distribution of ova diameter of E. teres collected from the Egyptian Mediterranean water, off Alexandria throughout December, January, February, March, and April (2008).

3.8. Histological Studies. In the present work, annual ovarian and testicular cycle of E. teres were studied throughout the period of investigation from January to December for both sexes to identify maturity stages and confirm time and mode of spawning as well as structure of gonads.

3.8.1. Oogenesis of Etrumeus teres. Developmental stages of ovaries was divided into six stages, immature, mature, vacuolization, yolk deposition, ripening, and spawning and spent stage.

3.8.2. Immature Stage. During this stage oogenesis showed three changes starting from oogonia to primary oocytes and then secondary oocytes (Figure 5(a)). The oogonia (oog) were small rounded cells with relatively clear zone of cytoplasm. They observed either solitary or in small nests. Oogonia ranged in diameter from $11 \mu$ to $15 \mu$. Primary oocytes (Po) were mostly polygonal and ranged from $22.5 \mu$ to $35 \mu$ in diameter. The nucleus of such cell ranged from $12.5 \mu$ to $17.5 \mu$ in diameter. Secondary oocytes (So) ranged from $80 \mu$ to $95 \mu$ in diameter. Its nucleus reached $35 \mu$ in diameter (Figure 5(a)). This stage was recorded throughout the year, but it dominated during September, October and decreased in November.

3.8.3. Mature Stage. At this stage oocytes and their nuclei increased in size. Oocyte was surrounded by isolated layer of follicular epithelium (FE). The oocyte was polygonal or hexagonal. At early stage oocyte ranged from $92.5 \mu$ to $105 \mu$ with a nucleus diameter ranging from $37.5 \mu$ to $40 \mu$. At the end of this stage oocyte increased in diameter reaching $112.5 \mu$ with a nucleus diameter ranging from $40 \mu$ to $50 \mu$. The follicular epithelium ranged from $1 \mu$ to $2.5 \mu$ thickness. Few numbers of small bright rounded spots (yolky nucleolus $(Y n)$ ) were observed in the cytoplasm of such oocytes by the end of this stage (Figure 5(b)). This stage dominated in late November, December, and early January.

3.8.4. Vacuolization Stage. At the beginning of this stage few numbers of small-sized vacuoles (V) were detected. Such vacuoles arranged in one or two rows in the cytoplasm (Figure 5(c)). Oocyte ranged from $162 \mu$ to $195 \mu$ in diameter with nucleus ranging from $67 \mu$ to $70 \mu$. The vacuoles' diameter ranging from $12 \mu$ to $20 \mu$. At the end of this stage 


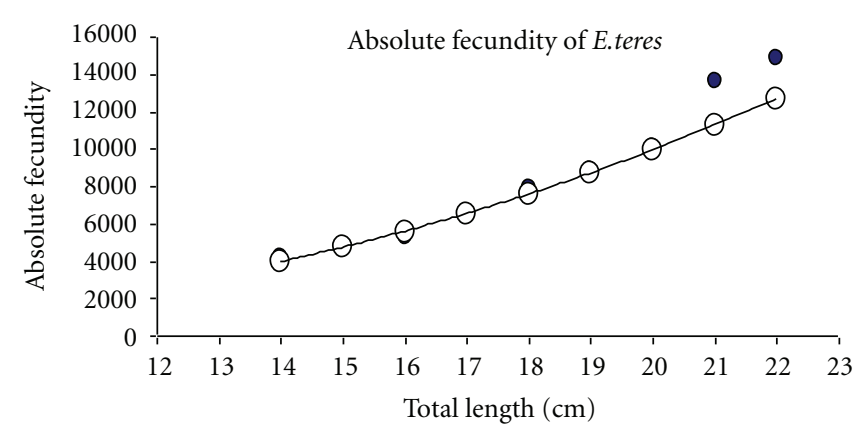

(a)

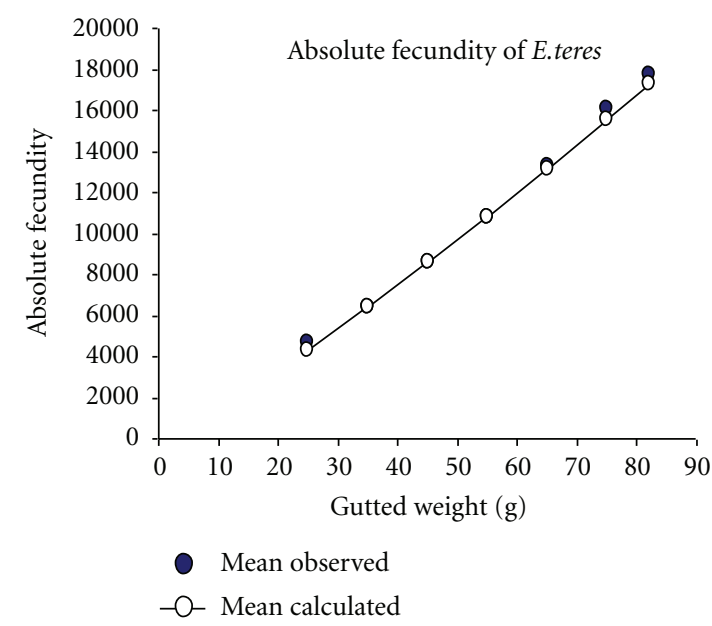

(c)

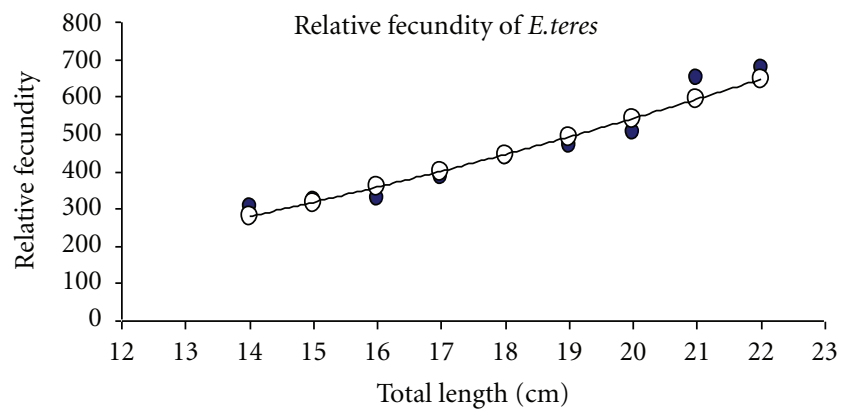

(b)

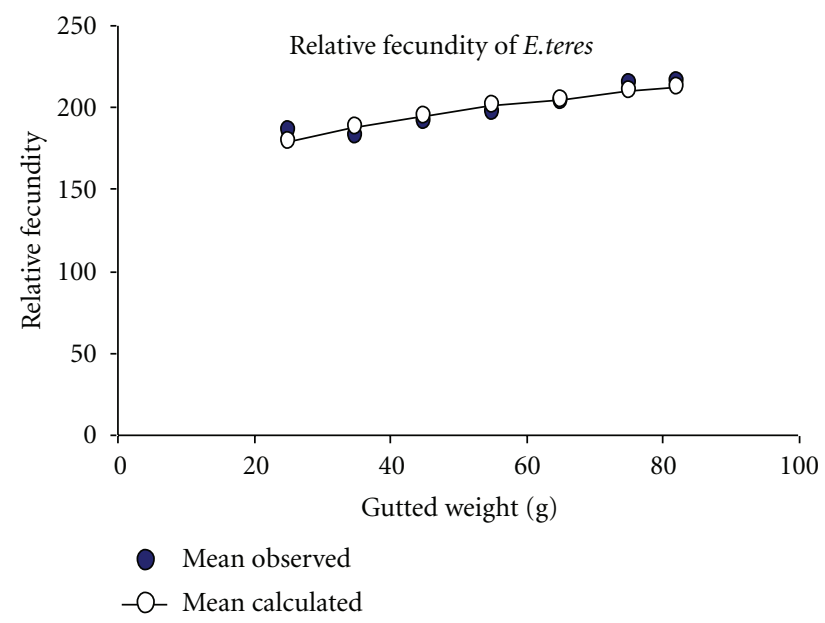

(d)

FIgURE 4: The mean observed and calculated values of absolute and relative fecundity per length (a,b) and per gutted weight (c,d) for E. teres collected from the Egyptian Mediterranean water, off Alexandria during the period of spawning season (2008).

vacuoles increased in number and size and arranged in several rows in the cytoplasm. The diameter of the oocyte ranged from $370 \mu$ to $380 \mu$ with nucleus ranging from $80 \mu$ to $110 \mu$. Vacuoles diameter ranged from $7.5 \mu$ to $12 \mu$. The follicular epithelium (FE) became more conspicuous, and an additive layer of zona radiata (ZR) was formed. Zona radiata measured about $16 \mu$, and the follicular epithelial layer measured $3 \mu$ thickness. An inner most cortical alveoli layer appeared (Figure 5(c)). This stage was recorded during late January, February, and March with high peak in February.

3.8.5. Yolk Deposition Stage. At this stage the yolk granules deposited in the cytoplasm. Oocyte ranged from $390 \mu$ to $560 \mu$ in diameter with a nucleus ranging from $80 \mu$ to $120 \mu$. The yolk granules were scattered in the cytoplasm, and their diameter ranged from 5 to $10 \mu$. Zona radiata ranged from $10 \mu$ to $25 \mu$, and the diameter of follicular epithelium ranged from $4 \mu$ to $6 \mu$ in thickness. Vacuoles were scattered in cytoplasm, and their diameter ranged from 4 to $8 \mu$. At the end of this stage many vacuoles were fused to each other, and yolk granules began to liquefy (Figure 5(d)). This stage appeared during spawning season and dominated in February, March, and April.
3.8.6. Ripening Stage. At this stage, the size of the oocyte ranged from $590 \mu$ to $620 \mu$ in diameter with a nucleus ranging from $100 \mu$ to $120 \mu$ which migrated towards the animal pole (Figure 6(a)). The nucleus appeared intermingled with the cytoplasm. The vacuoles increased in size reached $20 \mu$ and mixed with the liquefied yolk granules. The oocyte membrane of $E$. teres had four distinct layers: the follicular epithelial layer (FE), a median zona radiata (ZR) as a cellular layer which consists of two layers (outer zona radiata (OZR) + inner zona radiata (IZR) and an inner cortical alveoli (CA) (Figure 6b). The thickness of epithelial layer ranged from 4 to $6 \mu$, and zona radiata ranged from $18 \mu$ to $22 \mu$. This stage is the most important indicator of the spawning season. It was recorded during all spawning months from December to May with peak in April.

3.8.7. Spawning and Spent Stage. At this stage, the ripe ova were discharged from the ovary. Empty follicle (EF) was observed in the ovary. The residual eggs undergo atresia (atretic oocytes $(\mathrm{AO})$ ), and the new generations of cytoplasmic growth cells were observed (Figure 6(c)). The cytoplasmic yolk undergoes phagocytosis, and gradually the yolk vesicles become empty vacuoles. Then the yolk contents were completely resorbed and disappeared. Gradually the 


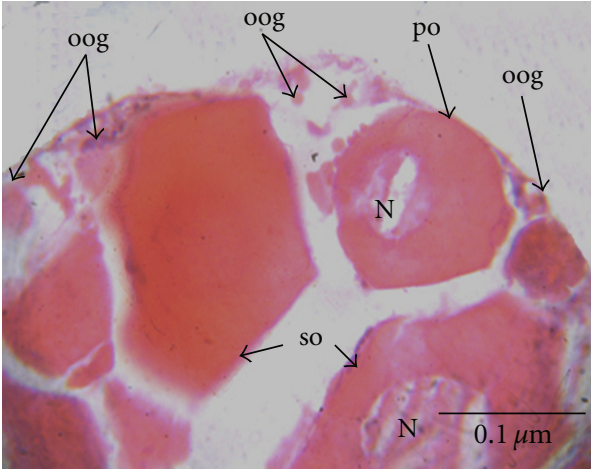

(a)

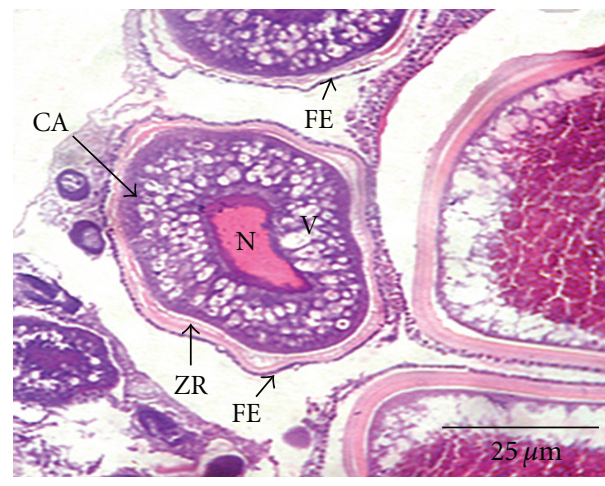

(c)

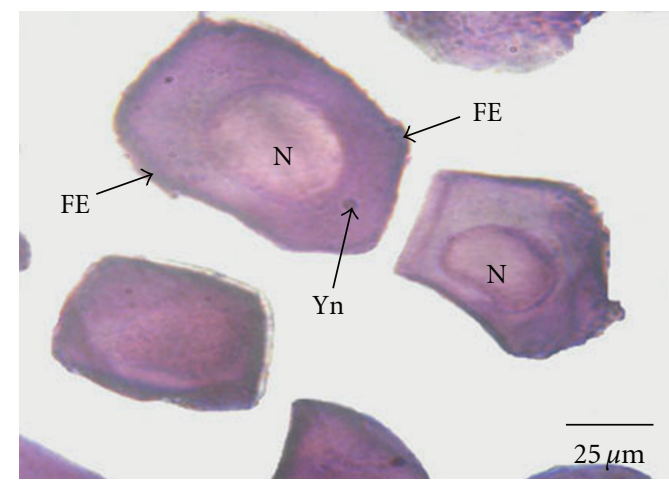

(b)

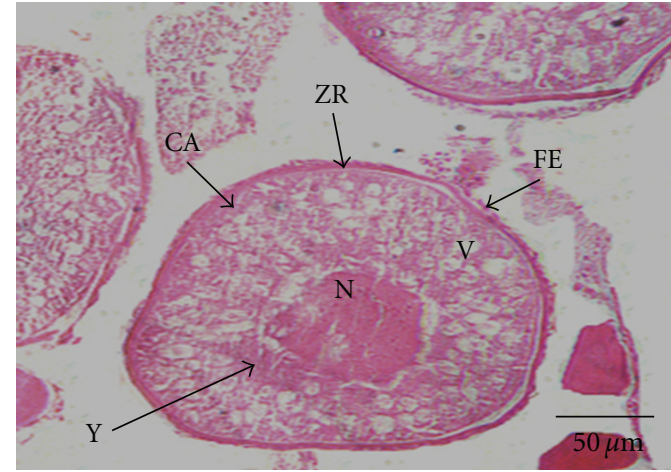

(d)

FIGURE 5: Photomicrograph of section in ovary of E. teres at immature stage (a), mature stage (b), vacuolization stage (c), and yolk deposition stage (d). Primary oocyte: po, secondary oocyte: so, oogonia: oog, nucleus: N, follicular epithelial: FE, yolky nucleolus: Yn, vacuoles: v, zona radiate: ZR, inner cortical alveoli: CA. Stained with haematoxylin and eosin ( $\mathrm{H}$ and $\mathrm{E})$.

whole follicle disappears in the ovarian stroma. This stage was recorded during the period from June and July.

3.8.8. Spermatogenesis of Etrumeus teres. Developmental stages were divided into five stages: immature, mature, nearly ripe, ripe, and spawning and spent stage.

3.8.9. Immature Stage. Testis of E. teres contained seminiferous tubules separated by interlobular connective tissues. At immature stage seminiferous tubules were filled with spermatogonia (spg) cells with little number of primary spermatocytes (ps) (Figure 7(a)). Spermatogonia were rounded in shape with faintly stained cytoplasm. They had spherical nucleus with distinguishable nuclear membrane. Spermatogonia ranged from $10 \mu$ to $15 \mu$ in diameter. This stage was recorded throughout the year, but it dominated during August, September, and October.

3.8.10. Mature Stage. Spermatogonia, primary and secondary spermatocytes were detected at the beginning of this stage. The primary spermatocytes (ps) and the secondary spermatocytes (ss) were smaller in diameter than the spermatogonia. At late mature stage few nests of spermatids (SPD) were detected. The diameter ranged from $6 \mu$ to $7.5 \mu$ for primary spermatocytes and from $4 \mu$ to $5 \mu$ for secondary spermatocytes (Figure 7(b)). This stage was observed from December to February.

3.8.11. Nearly Ripe Stage. At this stage, testis showed more active spermatogenesis process. The number of spermatogonia and primary spermatocytes reduced, while secondary spermatocytes and spermatids cells were the dominant cell types. Few lobules of spermatozoa were detected. Spermatids ranged in diameter from $2.5 \mu$ to $3.5 \mu$. Spermatozoa ranged from $1 \mu$ to $1.5 \mu$ in diameter. This stage dominated during February, March, and April.

3.8.12. Ripe Stage. Fair quantity of spermatozoa (ranged from $1 \mu$ to $1.5 \mu$ ) was detected in the seminiferous tubules at the beginning of this stage. Remarkable quantity of spermatids and few numbers of spermatogonia, primary spermatocytes and secondary spermatocytes were observed in the testis. The interlobular connective tissues separated the seminiferous tubules (Figure $7(\mathrm{c})$ ). This stage was recorded during spawning time but its high peak was during February to April.

3.8.13. Spawning and Spent Stage. This stage represented an extension for ripe stage. At that time sperm cells were discharged from seminiferous tubules which in turn reduced 


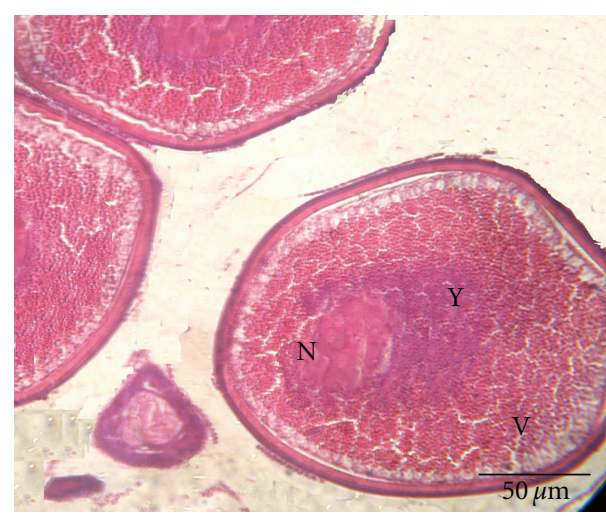

(a)

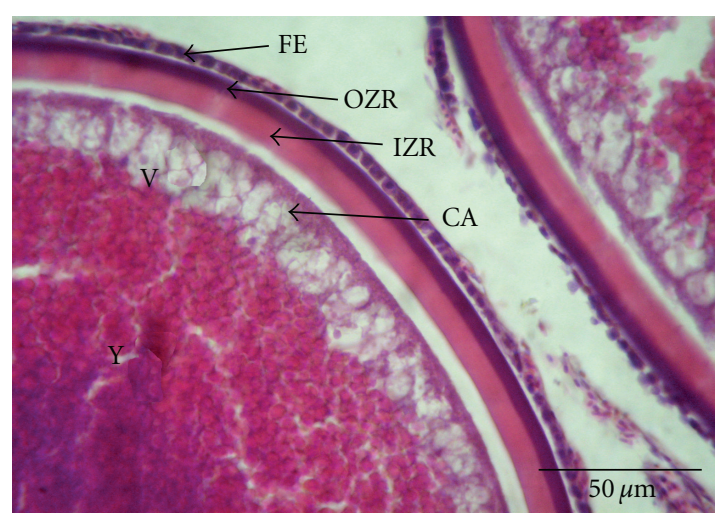

(b)

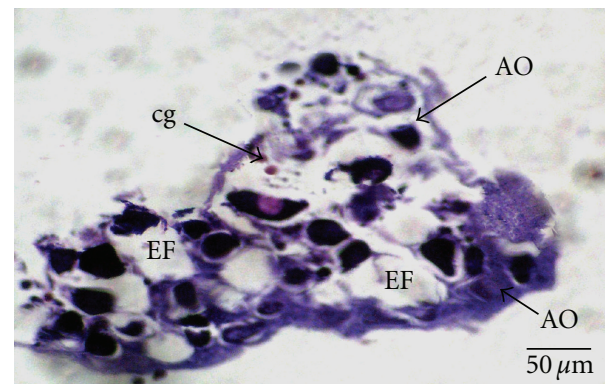

(c)

FIGURE 6: Photomicrograph of section in ovary of E. teres at ripening stage (a, b) and spent stage (c). Nucleus: N, yolk granules: Y, vacuoles: V, outer zona radiate: OZR, inner zona radiate: IZR, inner cortical alveoli: CA, atretic oocyte: AO, empty follicle: EF, cytoplasmic growth cells: cg. Stained with haematoxylin and eosin ( $\mathrm{H}$ and $\mathrm{E})$.

in size. Spermatogenesis completely stopped to form spent testis (Figure $7(\mathrm{~d})$ ). New generation of spermatogonia were recorded at the periphery of many tubules. This stage was recorded during July and August.

\section{Discussion}

In the present work, maturity stages of E. teres based on scale of Nikolsky [16] were divided into six stages: I immature, II resting stage, III mature, IV nearly ripe, $\mathrm{V}$ ripe, and VI spent stage. Nearly the same sequencing has been previously reported by Hassan and Allam [22-24]. According to the present results, monthly distribution of maturity stages showed that ripe stage of $E$. teres appeared in December then increased to record the highest peak in April. Such stage ended in May for female and in early July for males. This means that E. teres in the Egyptian Mediterranean water had prolonged spawning season extending from December to May for females and to July for males. The same results have been previously recorded by El-Sayed and Plaza et al. $[12,13]$ on the same species collected from the Gulf of Suez and Tosa Bay, respectively. In contrast to the present results, mature and ripe stages of some species of family clupeidae and other pelagic fishes were dominant during the months of summer and autumn [11].

The length and age at first sexual maturity are very important parameter in fisheries research to assess the optimum age of first capture of a species and to determine minimum legal size that may be needed to maintain the suitable spawning stock and to ensure at least one spawning for the mature individuals [25]. Length at first sexual maturity of E. teres was $12.6 \mathrm{~cm}$ for male and $13.1 \mathrm{~cm}$ for female. El-Sayed [12] mentioned that the length at first sexual maturity of E. teres collected from the Gulf of Suez was $12.0 \mathrm{~cm}$ for female and $12.2 \mathrm{~cm}$ for males. The present results were not compatible with those of Sanders et al. [26]. They reported that the length at first sexual maturity of E. teres collected from Gulf of Suez was $16.36 \mathrm{~cm}$ for female and $16.17 \mathrm{~cm}$ for males with age 1.73 and 1.70 years old for females and males, respectively. Roel and Melo [27] stated that length at first sexual maturity of Etrumeus whitehead collected from Eastern Cap (South Africa) was $14.5 \mathrm{~cm}$ for both sexes. The age of maturation depends on the environmental conditions as well as the nature of the population itself [28].

The application of sex ratio is useful in the study of spawning population [11]. The numbers of females of round herring were higher than those of males during whole period except December and April. Also females were the dominant at different reproductive length groups with exclusion of one length group $(24 \mathrm{~cm})$. In the latter length group the males were more abundant. Generally females accounted $66.62 \%$ and males accounted $33.38 \%$ of the total collected samples with significant difference $\left(\chi^{2}=72.4 ; P<.05\right)$. El-Sayed [12] stated that the numbers of males of E. teres collected 


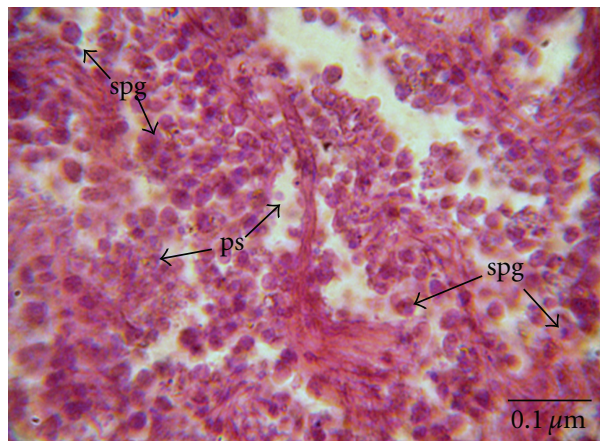

(a)

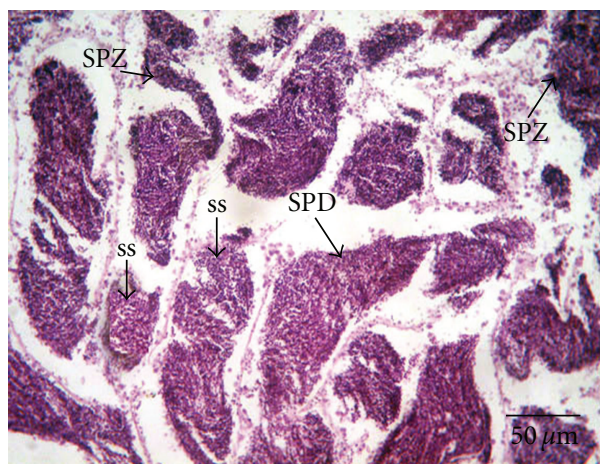

(c)

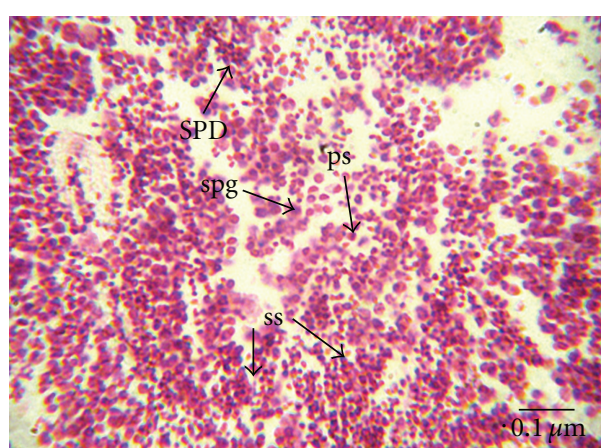

(b)

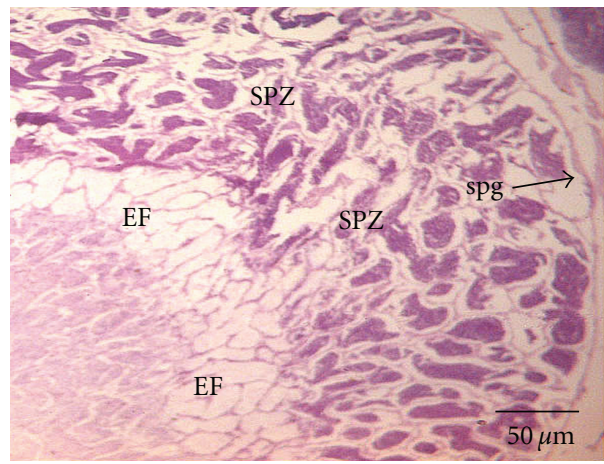

(d)

Figure 7: Photomicrograph of section in testes of E. teres s at immature stage (a), mature stage (b), ripening stage (c), spent stage (d). Spermatogonia (spg), primary spermatocyte (ps), secondary spermatocytes (ss), spermatids (SPD), spermatozoa cells (SPZ), empty follicle (EF). Stained with haematoxylin and eosin ( $\mathrm{H}$ and $\mathrm{E})$.

from Gulf of Suez were higher that the number of females during the period from December to March, while females accounted higher percentage during April, May, October, and November. In contrast to the present results he concluded that females accounted $49 \%$ while males accounted $51 \%$ of the total samples. These differences may be attributed to the difference in the time of spawning season or may be due to prespawning migration of males [29].

Gonadosomatic index (GSI) has been widely used as a low-cost indicator of reproductive condition and spawning time in fishes $[12,13]$. In the present work, both sexes of E. teres showed that GSI values were high during breeding season for both sexes which started in December and ended in May for female and in early July for males. These findings were nearly similar to those of El-Sayed [12] on E. teres collected from the Gulf of Suez and Plaza et al. [13] on E. teres collected from Tosa Bay. These authors stated that this species spawns during winter and spring seasons. The recorded fluctuations in the GSI values for males and females of $E$. teres in the present work mean that this species is multi spawner. The same result has been concluded by El-Sayed and Plaza et al. [12, 13]. According to Moyle and Cech [28], the ovaries of teleost fishes are several times larger than the testes. So, the GSI is always higher in females than in males, particularly during breeding season [20]. The present work and that of El-Sayed [12] on E. teres reported that GSI values for males were higher than those for females during the breeding season. Such difference may be attributed to the need of males to produce larger amounts of sperms to ensure eggs fertilization.

Hepatosomatic index (HSI) for fishes can give a picture about the ability of fishes to store fatty substances. HSI changed according to the variations in the feeding habits and reproductive behavior [14]. In the present work HSI values for females increased from December to April and from December to July for males. Both sexes of E. teres showed the same correlation between GSI and HSI during their breeding season, indicating that liver activity was high during breeding season. For most teleosts the liver is the place of yolk (vitellogenin) synthesis during the exogenous vitellogenesis. Hence, the liver might enlarge (more than males) during the female reproductive season as a response to vitellogenin needs [30]. However, the relationship between liver and ovary weight is not always as strong and positive as could be expected [31]. Hepatosomatic index is also an indicator of recent feeding activity [32].

In the present work, during exogenous vitellogenesis an obvious increase was observed in the GSI and HSI values. During this stage the liver synthesized vitellogenin (high HSI values) and secreted it in the blood stream. Subsequently, it is transported to the ovary, where the oocytes absorb the plasma vitellogenin by means of pinocytosis (high GSI values). Also, the present finding can reflect a synchronism between reproduction and vitellogenin uptake throughout 
the protracted spawning whereas the ovary gains more weight compared to the liver, which is indicative that vitellogenin uptake stops and/or decreases in final oocyte maturation stage [13]. This finding is further supporting the multiple spawning strategy of $E$. teres. This case was found by Al-Absawy [20] on Trachinotus ovatus collected from the Egyptian Mediterranean water and by Plaza et al. [13] on E. teres collected from Tosa Bay, Southern Japan. The presence of high HSI values during breeding season in the present work could be attributed to storing of materials needed to vitellogenesis and also may be ascribed to feeding habits whereas this species had high feeding intensity during breeding season [32].

According to Yoshida [33] and El-Ganainy [15], analysis of ova diameter provides evidences on the duration of spawning process and spawning habits, whether prolonged or short. The short spawning season was characterized by a single group of matured eggs, while the long spawning encountered several batches of matured eggs. In the present work ova of E. teres were divided into two groups of eggs (transparent immature egg and yolky eggs). Yolky eggs were recorded from December to April. The peak of yolky eggs as well as GSI was in April. This observation proved that E. teres had long spawning season. Yoshida [33] reported that the presence of two or more modes of ova size frequencies in the ovary indicates the extended spawning season. The detection of different sized groups of eggs in ripe ovaries during spawning period of E. teres indicated that this fish was multi spawner. Similar results have been recorded by El-Sayed and Plaza et al. $[12,13]$ on E. teres collected from different localities.

Most clupeids are multiple spawners with indeterminate fecundity having more than one group of yolked oocytes coexisting in mature ovaries [13]. In the present work, the absolute and relative fecundity of E. teres increased with increasing of length and weight. These results were in agreement with those of El-Sayed [12] for E. teres collected from the Gulf of Suez and Plaza et al. [13] for E. teres collected from Tosa Bay, Southern Japan. The difference in the number of ova for the same length group may be related to environmental factors and ova size $[13,34]$. According to Plaza et al. [13] E. teres had egg size larger than other multiple spawner clupeids. The productions of larger eggs lead to a reduction in batch fecundity. This seems to be true for E. teres in the present work and that of El-Sayed [12].

In the present work, the ovarian cycle of E. teres was classified histologically into six stages: (1) immature, (2) mature, (3) vacuolization, (4) yolk deposition, (5) ripening, and (6) spawning and spent stage. The same stages have been previously reported by Al-Absawy, El-Gharabawy, Assem, and Mourad [20,35-37]. In the present work, the cells of the immature stage were small rounded with relatively clear zone of cytoplasm. This stage contained three changes oogonia, primary and secondary oocyte. According to Herrera et al. [38] the appearance of follicular epithelial is considered as indicator for synthesis of sexual steroids. In the present work, oocytes at mature stage of E. teres had an isolated follicular epithelium layer. The present results agreed with those of Plaza et al. [13] for E. teres and Mourad [37] for M. cephalus and L. ramada. The yolky oocytes were observed in more than one mode with variable sizes. This means that E. teres is multiple spawner. This case of yolk deposition in the oocyte of $E$. teres was also described by many authors for different fish species [13, 20, 35, 36, 39].

Ripening stage in the present work was characterized by migration of nucleus towards the cell animal pole. Membrane of ripe oocyte consisted of different layers, these layers can varies according to habitat whether it fresh or marine species. Ripe oocyte membrane of E. teres had four distinct layers: an outer follicular epithelial layer, a median zona radiata (outer zona radiata + inner zona radiata) and inner cortical alveoli. Mekkawy and Osman [40] who reported that oocyte membrane of $C$. gariepinus had four distinct layers: an outmost follicular epithelial layer (outer theca + inner granulose), a median zona radiate, and inner cortical alveoli. According to Riehl and Greven [41] many oviparous teleosts exhibited a division of the zona radiata into two or more layers. In the present work, E. teres had two layers of zona radiate. In contrast to the present result Al-Absawy [20] recoded a single layer of zona radiate in Trachinotus ovatus. Cotelli et al. [42] reported that Carassius auratus had a three-layered zona radiata. The difference in structure of zona radiata may be attributed to the habitat of species whether pelagic or demersal species. Also such difference may be due to the type of fishes (oviparous or viviparous) [41].

Spawning and spent stage of E. teres was characterized by displaying various peculiarities of the spawning season. The ovary of this stage had a large number of empty follicles and different stages of yolk deposition oocytes. During this stage ripe ova were discharged, and early stages of cytoplasmic growth were observed as a new generation for the next breeding season. This finding was in correlation with those of Plaza [13] for E. teres. The presence of postovulatory follicles (empty follicles) in partially spent ovaries indicated that at least one batch of eggs has been spawned. Furthermore, the presence of less advanced and advanced mode of oocyte with different sizes in the ripe and spawning ovary indicated that fish species has prolonged spawning season [43]. According to present results, E. teres is a multiple spawner and has prolonged spawning season with a group-synchronous ovarian which contained oocytes at all stages of development and spawned many times during breeding season. This conclusion was previously concluded by El-Sayed [12] and Plaza et al. [13] for the same species.

Spermatogenesis of E. teres during the annual reproductive cycle showed a pattern of testicular cycle. The seasonal testicular cycle in the Etrumeus teres was studied and classified into five stages: (1) immature, (2) mature, (3) nearly ripe, (4) ripening, and (5) spawning and spent $[20,44,45]$. The annual testicular cycle of E. teres showed that spermatogenic activity extended from December to July. Al-Absawy [46] reported that the spermatogenic activity of Sparus aurata was extended from September to March containing all types of spermatogenic cells at different developmental stages. The spermatogenic activity of Trachinotus ovatus was extended from May to September containing all 
types of spermatogenic cells at different developmental stages [20]. This means that there are differences in the time of spermatogenic activity which may be due to the differences in the time of spawning season.

During immature stage of E. teres spermatogenesis and primary germ cells undergo several successive miotic divisions to form spermatogonia which was the dominant structure. Spermatogonia were detected throughout the year in the peripheral zone of the testis, but were greatly reduced in number during the breeding season. Spermatids were differentiated into spermatozoa at nearly ripe stage. Few lobules of spermatozoa were detected in the testis of this stage. In the ripening stage the spermatozoa discharged out from seminiferous tubules and released into the lobular lumen through the spermiation process. The sperm was then hydrated before its release [47-49]. By the end of this stage, numerous blood corpuscles appeared in the interlobular connective tissues and spermatogenesis completely stopped to form spent testis. New generation of spermatogonia were observed at the periphery of many lobules. The presence of new generation of spermatogonia at the periphery of many lobules may be inducing the multiplication for next spawning. The specific characteristics of spermatogenesis are related to the type of spawning, which means whether it is short or long. Sperm discharge likewise depends on the character of spawning in the female, which means whether it is uni- or multiportional. The present study showed that the presence of different sizes of oocytes at different developmental stages of maturation (mature, nearly ripe, and ripe) during the spawning season refers to presence of different sizes of spermatocytes at different developmental stages of maturation (mature, nearly ripe, and ripe) during the same season. This indicated that $E$. teres is multi spawner and a synchronous species. Also the present work showed that male of E. teres has prolonged spawning season with variations in the spermatogenic activity (partial discharge of spermatozoa). This may reflect the suitability of the specific reproductive behavior of male E. teres and its adaptation to the prolonged spawning season with females. The present results were supported by the findings of Assem [50] in O. melanura, Zaki et al. [44] in M. seheli, Assem [51] in S. vulgaris and $S$. aegyptiaca, El-Boray [52] in R. haffara, Assem [53] in $C$. cryosis, Al-Absawy [20] in T. ovatus, and Al-Absawy [45] in M. merluccius.

On the other hand, both male and female of E. teres would take short period before starting new reproductive cycle named quiescent period, which came after spawning and spent period. In the present work quiescent period started in June and ended in October for female, while it started in late July and ended in October for males. Assem [51] stated that throughout the period from April to late August spermatogenic activity in S. vulgaris and S. aegyptiaca slowed down and passed through a period of quiescent phase. Also, she reported that throughout the period from November to late March spermatogenesis in C. cryosis passed through a period of quiescent phase. The differences in this period in different species may be due to the differences in the time of spermatogenic activity.

\section{References}

[1] R. Yilmaz and B. Hossucu, "Biological parameters of round herring, Etrumeus teres (De Kay, 1842) in the Gulf of Antalya (Mediterranean Sea)," E.U. Journal of Fisheries \& Aquatic Sciences, vol. 20, pp. 1-8, 2003.

[2] P. Whitehead, "A revision of the recent round herrings (Pisces: Dussumieriidae)," Bulleten of British Museum of Natural History (Zoology), vol. 10, pp. 305-380, 1963.

[3] R. Froese and D. Pauly, Concepts, Design and Data Sources, ICLARM, Los Banos, Philippines, 2000.

[4] R. El-Sayed, Check-list of Egyptian Mediterranean Fishes, vol. 77, Bulleten of National Institute of Oceanography and Fisheries, Alexandria, Egypt, 1994.

[5] N. Basusta, U. Erdem, and S. Mater, "Iskenderun Körfezi'nde yeni bir Lesepsiyen göçmen bahk türü; Kizilgözlü Sardalya, Etrumeus teres (Dekay, 1842)," in Proceedings of the Mediterranean Fisheries Congress, pp. 921-924, Izmir, Turkey, April 1997.

[6] D. Golani, "The Lessepsian migrant, the Red-eye round herring, Etrumeus teres (DeKay, 1842), a new record from Cyprus," Zoology in the Middle East, vol. 20, pp. 61-64, 2000.

[7] M. Falautano, L. Castriota, and F. Andaloro, "First record of Etrumeus teres (Clupeidae) in the central Mediterranean Sea," Cybium, vol. 30, no. 3, pp. 287-288, 2006.

[8] P. Kasapidis, P. Peristeraki, G. Tserpes, and A. Magoulas, "A new record of the Lessepsian invasive fish Etrumeus teres (Osteichthyes: Clupeidae) in the Mediterranean Sea (Aegean, Greece)," Aquatic Invasion, vol. 2, pp. 152-154, 2007.

[9] M. M. Farrag, Fishery biology of Red Sea immigrant Etrumeus teres (family: Clupeidae) in the Egyptian Mediterranean water, off Alexandria, M.S. thesis, Al-Azhar University (Assiut branch), Assiut, Egypt, 2010.

[10] E. K. Akel, "Fisheries of experimental purse seine net using light and population dynamics of Sardinella aurita (Family clupeidae) east of Alexandria, Egypt," Egyptian Journal of Aquatic Boilogy and Fisheries, vol. 13, pp. 55-77, 2009.

[11] S. N. Faltas, Study of purse-seine fisheries in Egyptian Mediterranean water with special reference to the biology of sardine in catch, M.S. thesis, Alexandria University, Alexandria, Egypt, 1983.

[12] A. El-Sayed, Biological and Ecological studies on purse-seine fisheries in the Gulf of Suez, Ph.D. thesis, Suez Canal University, Ismailia, Egypt, 1996.

[13] G. Plaza, H. Sakaji, H. Honda, Y. Hirota, and K. Nashida, "Spawning pattern and type of fecundity in relation to ovarian allometry in the round herring Etrumeus teres," Marine Biology, vol. 152, no. 5, pp. 1051-1064, 2007.

[14] R. Love, The Chemical Biology of Fishes, Academic Press, London, UK, 1970.

[15] A. El-Ganainy, Biological studies on Lizard fishes Saurida undosquamis (Pisces, Synodontidae) from the Gulf of Suez, M.S. thesis, AinShams University, Cairo, Egypt, 1992.

[16] G. Nikolsky, The Ecology of Fishes (Transelated from Russian), Academic Press, London, UK, 1963.

[17] T. Pitt, "Distribution, abundance and spawning of yellow-pale flounder Limanda ferruginae in the new Founland area of the North-West Atlantic," Journal of the Fisheries Research Board of Canada, vol. 27, pp. 2261-2271, 1970.

[18] G. Snedecor and U. Press, Statistical Methods Applied to Experiments in Agriculture and Biology, The Low State University, 1956. 
[19] A. Philips, Biological studies on the main cichlid fishes of the Nozha Hydrodrome, Alexandria, Egypt, Ph.D. thesis, Zagazig University, Zagazig, Egypt, 2004.

[20] M. Al-Absawy, Reproductive and ultrastructure studies on gonads of Trachinotus ovatus (Family: Carangidae) from the Egyptian Mediterranean waters, Ph.D. thesis, Zagazig University Banha Branch, Banha, Egypt, 2004.

[21] T. Bagenal, Methods for assessment of fish production in freshwater, Blackwell Science, Oxoford, UK, 1978.

[22] M. Hassan, Comparative biological studies between two species of family sparidae Boops boops and Boops salpa in the Egyptian Mediterranean waters, M.S. thesis, Alexandria University, Alexandria, Egypt, 1990.

[23] S. Allam, "Reproductive biology of pelagic carangid fishes Trachinotus ovatus from the Mediterranean Sea," Journal of Egyptian German Society of Zoology, vol. 19B, pp. 45-57, 1996.

[24] S. Allam, "The reproductive biology of Bojue, Boops boops (L.), from the Mediterranean waters, off Alexandria, Egypt," Journal Aquatic Biology and Fisheries, vol. 9, pp. 73-86, 2005.

[25] E. Farrag, Population dynamics and management of some sparid fish species in Abu Qir-Bay, M.S. thesis, AlAzhar University, Cairo, Egypt, 2008.

[26] M. J. Sanders, S. M. Kedidi, and M. R. Hegazy, "Stock Assessment for the Round Herring (Etrumeus teres) cought by purse seine in the Gulf of Suez," UNDP/FAO.RAB/81/002/13.

[27] B. Roel and Y. Melo, "Reproductive biology of the round herring Etrumeus whiteheadi," South Afrian Journal of Marine Science, vol. 9, pp. 177-187, 1990.

[28] P. Moyle and J. Cech, Fishes, an Introduction to Ichthyology, Prentice-Hall, Upper Saddle River, NJ, USA, 5th edition, 2004.

[29] S. Rizkalla, Fishery biology studies on family sphyraenidae in the Egyptian Mediterranean waters, M.S. thesis, Alexandria University, Alexandria, Egypt, 1985.

[30] R. Wallace and K. Selman, "Physiological aspects of oogenesis in two species sticklebacks, Gasterosteus aculeatus L. and Apeltes quadracus (Mitchill)," Journal of Fish Biology, vol. 14, pp. 551-564, 1979.

[31] M. Yoneda, M. Tokimura, H. Fujita et al., "Reproductive cycle and sexual maturity of the anglerfish Lophiomus setigerus in the East China Sea with a note on specialized spermatogenesis," Journal of Fish Biology, vol. 53, no. 1, pp. 164-178, 1998.

[32] J. A. Tomasini, D. Collart, and J. P. Quignard, "Reserve management strategy for the sand smelt from brackish lagoons in southern France," Journal of the Marine Biological Association of the United Kingdom, vol. 79, no. 1, pp. 145-151, 1999.

[33] M. Yoshida, "Skipjack Tuna spawning in the Marquesas Island and Tuamotu Archipelago," Bulleen Fish, vol. 65, pp. 479-488, 1966.

[34] D. L. Hay and J. R. Murphy, "Evaluating human choriogonadotropin heterogeneity in nongestational malignancy with monoclonal immunoassays," Oncology, vol. 44, no. 3, pp. 174179, 1987.

[35] M. El-Gharabawy, "Histomorphology of ovarian changes during the reproductive cycle of Lithognathus mormyrus (Teleostie, sparidae)," Journal Egyptian German Society Zoology, vol. 19, pp. 97-115, 1996.

[36] S. Assem, "The reproductive biology and histological characteristics of pelagic carangid female Caranx crysos from the Egyptian Mediterranean Sea," Journal of Egyptian German Society of Zoology C, pp. 195-215, 2000.

[37] M. Mourad, Effect of live food enrichment on survival and growth of marine larval fish with gonads properties studies, M.S. thesis, Alexandria University, Alexandria, Egypt, 2009.
[38] G. Herrera, E. Butos-obregon, and F. Balbontin, "Morphological aspects of gonadal maturation in the Hake," Revista de Biología Marina, vol. 24, no. 1, pp. 55-71, 1988.

[39] S. Salem, M. Zaki, M. El-Gharabawy, I. El-Shorbagy, and K. El-Boray, "Seasonal histological changes in the ovaries of Mugil seheli from Suez Bay," Bulleten of National Institute of Oceonagrphy and Fisheries, vol. 20, pp. 235-249, 1994.

[40] I. Mekkawy and A. Osman, "Ultrastructural studies of the morphological variations of the egg surface and envelopes of the A frican catfish Clarias gariepinus (Burchell, 1822) before and after fertilisation, with a discussion of the fertilisation mechanism," Scientia Marina, vol. 70, pp. 23-40, 2006.

[41] R. Riehl and H. Greven, "Fine structure of egg envelops in some viviparous Goodeid fishes, with comments on the relation of envelope thinness to viviparity," Canadian Journal Zoology, vol. 71, pp. 91-97, 1993.

[42] F. Cotelli, F. Andronico, M. Brivio, and C. L. Lamia, "Structure and composition of the fish egg chorion (Carassius auratus)," Journal of Ultrastructure Research and Molecular Structure Research, vol. 99, no. 1, pp. 70-78, 1988.

[43] T. Hunter and B. M. Sefton, "Transforming gene product of Rous sarcoma virus phosphorylates tyrosine," Proceedings of the National Academy of Sciences of the United States of America, vol. 77, no. 3, pp. 1311-1315, 1980.

[44] M. Zaki, S. Salem, M. El-Gharabawy, I. El-Shorbagy, and K. F. El-Boray, "Seasonal histological changes in the testes of Mugil seheli in Suez Bay," Bulleten of National Institute of Oceonagrphy and Fisheries, vol. 20, pp. 211-223, 1994.

[45] M. Al-Absawy, "Reproductive biology, spermatogenesis and ultrastructure of the testes of Gadidae fish Merluccius merluccius (Linnaeus 1758)," Egyptian Journal of Aquatic Boilogy and Fisheries, vol. 34, pp. 286-303, 2008.

[46] M. Al-Absawy, Reproductive physiology and induced spawning of Sparus aurata in marine hatchery of National Institute of Oceanography and fisheries, M.S. thesis, Alexandria University, Alexandria, Egypt, 1997.

[47] C. Hassin, The gonadal development in captive European sea Bass, Dicentrachus labrax and its hormonal control, M.S. thesis, TelAviv University, TelAviv, Israel, 1991.

[48] K. El-Boray, Reproductive biology and physiology characters of Mugil sehali, M.S. thesis, Tanta University, Tanta, Egypt, 1993.

[49] M. Abdo, Reproductive biology and induced spawning of Dicentracus labrux, Ph.D. thesis, Alexandria University, Alexandria, Egypt, 1996.

[50] S. Assem, Reproductive biology and physiology of one species of family Sparidae in Mediterranean Sea, M.S. thesis, Alexandria University, Alexandria, Egypt, 1992.

[51] S. Assem, Reproductive physiology and induced spawning of solea species, Ph.D. thesis, Alexandria University, Alexandria, Egypt, 1995.

[52] K. F. El-Boray, Reproductive biological studies on Rhabdosagus haffara in different water fish farms, Ph.D. thesis, Zagazig University, Zagazig, Egypt, 1997.

[53] S. Assem, "Reproductive biology, spermatogenesis and ultrastructure of testes of Caranx crysos (Mitchill, 1815)," Egyptian Journal of Aquatic Reseach, vol. 25, pp. 311-329, 1999. 

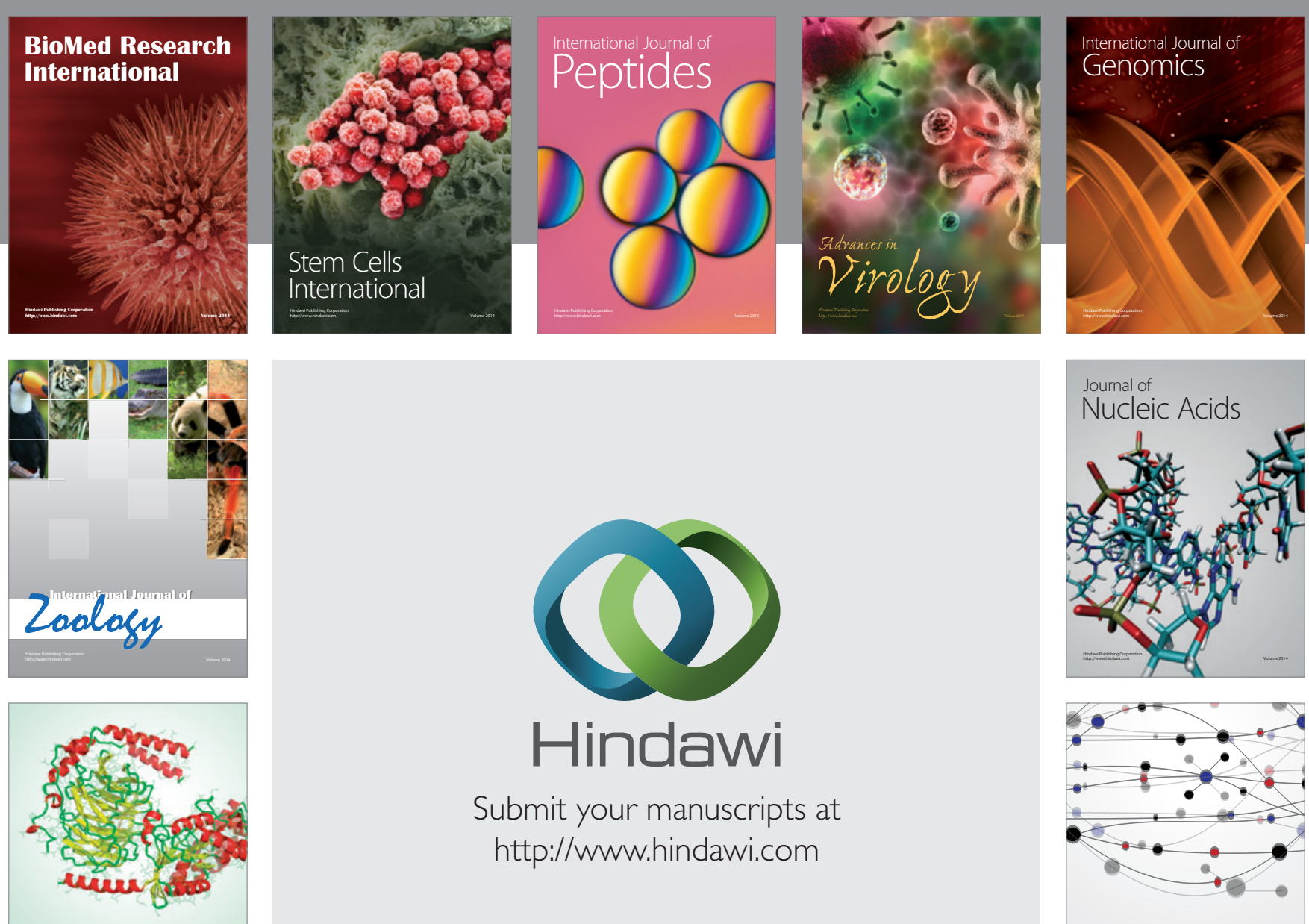

Submit your manuscripts at

http://www.hindawi.com

Signal ${ }^{\text {Jumal }}$ Transduction
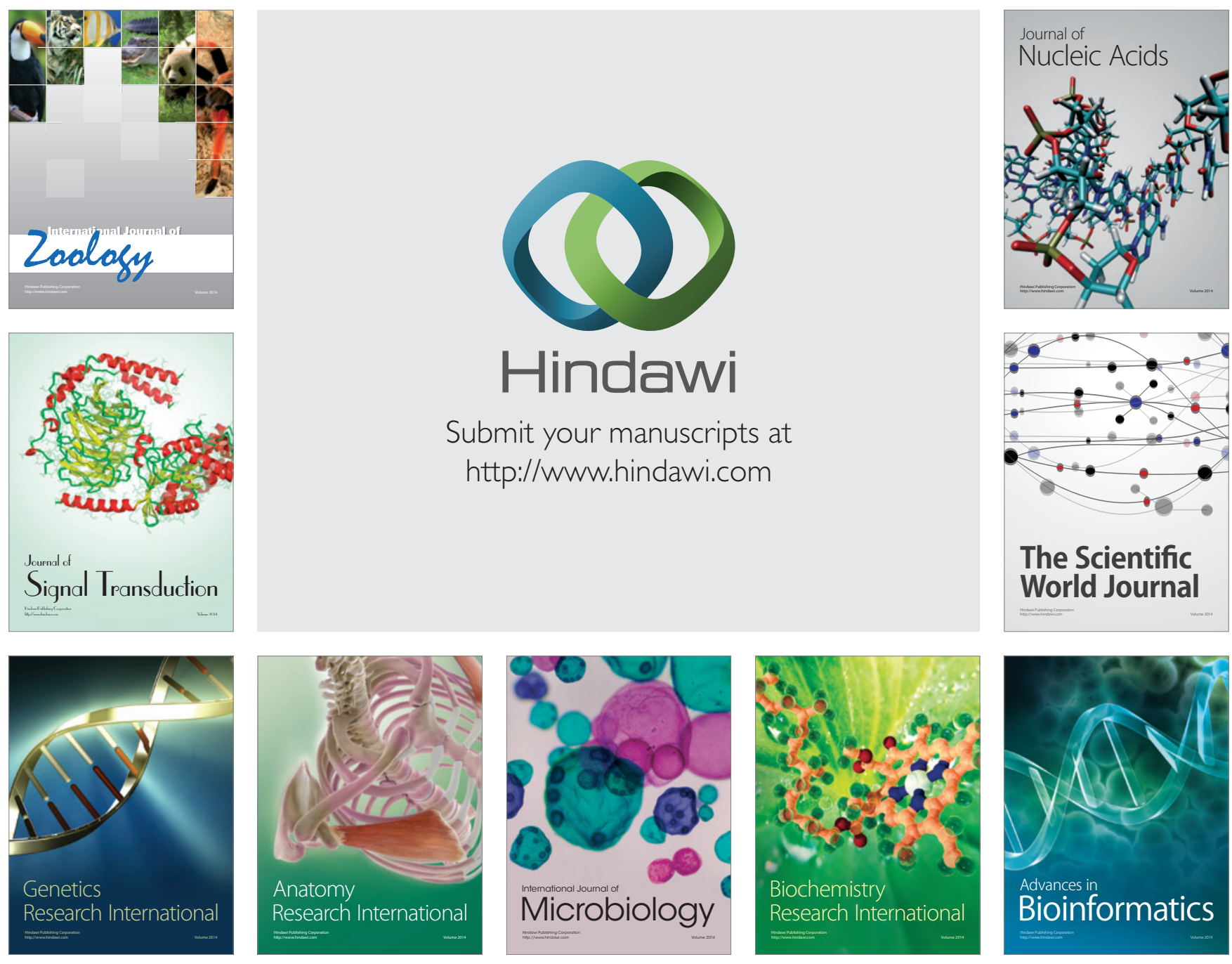

The Scientific World Journal
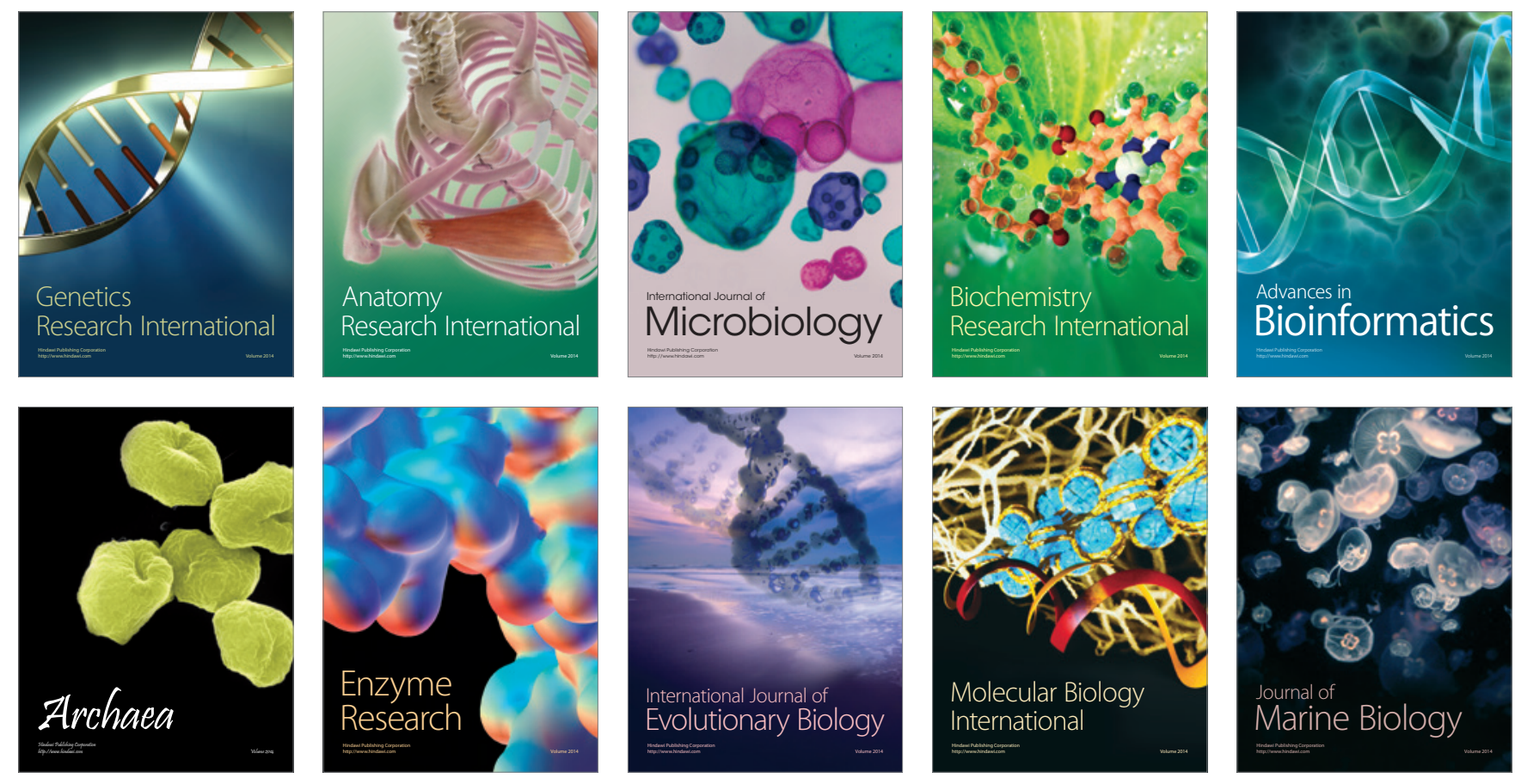